\title{
Nadir Benign Deri Eki Tümörü: Kutanöz Lenfadenoma
} A Rare Benign Skin Adnexal Tumor: Cutaneous Lymphadenoma

\section{Havva Hande Keser Şahin ${ }^{1}$ Orcid ID: 0000-0003-1827-1039, Yılmaz Baş ${ }^{1}$ Orcid ID: 0000-0002-4229-8568, Bayram Yilmaz ${ }^{1}$ Orcid ID: 0000-0002-1737-9446}

\author{
${ }^{1}$ Hitit Üniversitesi Erol Olçok Eğitim Araştırma Hastanesi, Tıbbi Patoloji Bölümü, Çorum, Türkiye.
}

\author{
Geliş Tarihi/Received: 09.10.2020 \\ Kabul Tarihi/Accepted: 28.05.2021 \\ Yazışma Adresi/Address for \\ Correspondence: \\ Uzm. Dr. Bayram Yilmaz \\ Hitit Üniversitesi Erol Olçok \\ Eğitim Araştırma Hastanesi, \\ Tıbbi Patoloji Bölümü, \\ Çorum, Türkiye.
}

E-mail: bayram.yilmaz7@saglik.gov.tr

\section{Anahtar Sözcükler: \\ Deri \\ Lenfadenom \\ Lenfoepitelyal tümör \\ Patoloji}

\section{Key Words:}

Skin

Lymphadenoma

Lymphoepithelial tumor

Pathology

\section{öz}

Kutanöz lenfadenom, trikoblastomun adamantoid varyantı olarak sınıflandırılan benign adneksiyal bir deri tümörüdür. Nadir görülmekte olup ayırıcı tanıda derinin sık görülen tümörü bazal hücreli karsinom mevcuttur. Nadir görülen bu benign deri eki tümörünün histopatolojik ve immünohistokimyasal bulgularını sunduk.

\begin{abstract}
Cutaneous lymphadenoma is a benign adnexal skin tumor classified as an adamantoid variant of trichoblastoma. It is rare and the differential diagnosis includes basal cell carcinoma, a common tumor of the skin. We presented the histopathological and immunohistochemical findings of a rare benign skin appendage.
\end{abstract}

\section{Giriş}

"Cildin benign kutanöz lenfoepitelyal tümörü" veya "kutanöz lenfadenom", nadir görülen, pilosebase kaynak।ı neoplazilerin spektrumuna dahil edilen benign adneksial bir tümördür. İlk olarak Santa Cruz ve Barr tarafından "cildin lenfopitelyal tümörü" olarak tanımlanmıştır (1). İntraepitelyal alanda yoğun lenfositik hücre reaksiyonu ve histiyositik hücreler ile bazaloid tarzdaki epitelyal hücrelerinin kendine özgü lobüler bir paternde dizilimiyle karakterizedir. Baş boyun bölgesinde, orta yaş kişilerde görülen nodüler lezyonlarda bazal hücreli karsinomdan ayırtedilmelidir(2).

\section{Olgu Sunumu}

29 yaşında kadın hastanın sol yanak derisinde lokalize, 6 aydır mevcut olan lezyon total eksize edilerek patoloji laboratuvarına gönderildi. Makroskopik incelemede $1.2 \times 0.8 \times 0.3 \mathrm{~cm}$ boyutlarda deri elipsi üzerinde en yakın cerrahi sınıra $0,1 \mathrm{~cm}$ uzaklıkta $1 \times 0.6 \times 0.2 \mathrm{~cm}$ boyutlarda, deri ile aynı renkte ve kubbe şeklinde papülonodüler bir lezyon izlendi. Mikroskopik incelemede kapsülsüz olan lezyon retiküler dermiste lokalize ve çevre normal dokudan belirgin bir sınırla ayrılmaktaydı. Tümör çok sayıda lenfoid hücre içeren yoğun bir fibröz stroma ile çevrelenmiş, değişik çapta, yuvarlak psödokistik paternde irregüler konturlu epitelyal lobüller halinde gelişmişti. Bu lobülleri periferik palizatlanma şeklinde dizilim gösteren 1-3 sıralı bazoloid hücreler çevirmekteydi. Lobüller içinde açık sitoplazmalı, nükleolleri belirgin büyük hücreler ve küçük lenfoid hücreler olmak üzere iki farklı hücre tipi gözlendi. Lenfositik infiltrat peritümöral alanda belirgindi. Subkutan yağ dokuya uzanım yoktu. Cerrahi sınırlar intaktı. Retraksiyon artefaktı izlenmedi (Şekil 1). İmmünohistokimyasal olarak tümör hücreleri pansitokeratin ile pozitif boyandı. EMA ile tümör içi epiteloid hücreler pozitif boyandı. Bcl-2 ile intratümöral ve peritümöral stromada izlenen lenfositler pozitifti. Intraepitelyal lenfoid komponent CD3 ile pozitif, CD20 ile 


\section{HMJ}

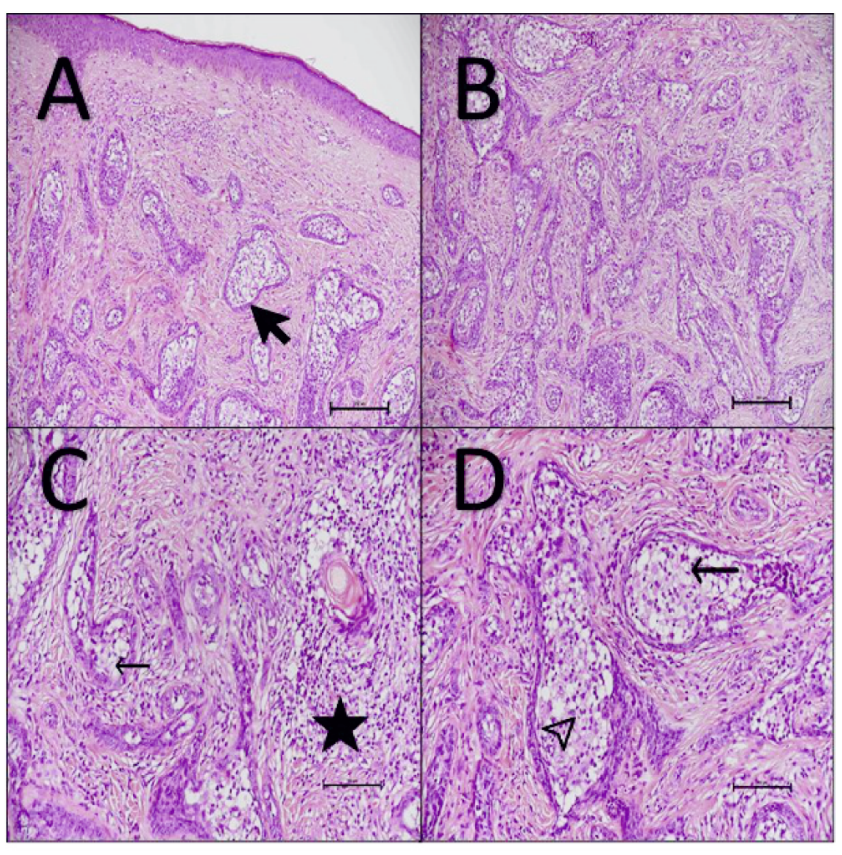

Sekil 1: Tümörün Histopatolojik Görüntüleri.

A: Dermiste yerleşmiş fibröz stromada psödokistik paternde düzensiz konturlu lobüllerden oluşan tümöral proliferasyon (4X, H\&E).

B: Tümör lobülleri; çevresinde retraksiyon artefaktı içermeyen periferik palizadlanma gösteren 1-3 sıralı bazoloid hücreler, açık sitoplazmalı, nükleolleri belirgin büyük hücreler ve lenfositlerden oluşmaktadır (4X, H\&E).

C ve D: Tümör büyük büyütme görüntüsü (20X, H\&E, ince ok; lobül içi lenfositler, ok başı; bazoloid hücreler, yıldız; büyük hücreler, kalın ok; tümör içi lenfositler).

fokal pozitifti. Lobül içinde S100 pozitif dendritik hücreler, izole CD30 pozitif "büyük hücreler" vardı. CD15 ile CD30 pozitif hücrelerde daha az oranda soluk boyanma izlendi. CD34 ile tümörde boyanma izlenmedi (Şekil 2). Olgunun 3 yıllık takibinde lezyon tekrarlamadı. Hastadan olgu sunumu için bilgilendirilmiş onam formu alınmıştır.

\section{Tartışma}

Kutanöz lenfadenom literatürde epitelyo-lenfohistiyositik tümör $(3,4)$, lenfotropik adamantinoid trikoblastom (5) gibi çeşitli isimler altında bildirilmiştir. Bazı çalışmalarda bazal hücreli karsinom (2) ya da desmoplastik trikoepitelyoma (6) ile ilişkili olduğu iddia edilmiştir. Ter bezlerinin immatür tümörü olan "lenfotropik solid syringoma" ile ilişkili olduğu da belirtilmektedir (7). Tümör, en son WHO sınıflandırmasında trikoblastomun adamantoid bir varyantı olarak benign foliküler tümörler arasında sınıflandırılmıştır (8).

Biz bu çalışmamızda tipik histomorfolojik ve immünohistokimyasal bulgularıla kutanöz lenfadenom olgusunu sunduk. Olgumuzda tümör içi lenfositlerde CD3 ile yaygın pozitif izlenmekte iken CD20 ile fokal daha az oranda pozitiflik saptandı. Alsadhan ve ark. (2) ve Fujimura ve ark. (9) yaptıkları çalışmalarda da lenfohistiyositik bileşen, T ve B lenfositlerinin polimorfik bir popülasyonundan oluştuğunu belirtmektedirler.

Kutanöz lenfadenomun morfolojik özellikleri, yardımcı immünohistokimya kullanılmadan da rutin hematoksilin eozin boyasında doğru tanıya izin verecek kadar belirgindir (10). Ana histolojik ayırıcı tanı, bazal hücreli karsinom ve siringoma, dermal timus ve lenfoepitelyoma benzeri deri karsinomunun açık hücre varyantlarını içerir (10). Yüzeyde izlenen nekroz nedeniyle deride izlenebilecek başka nekroz nedenleri de akılda tutulmalıdır (11).

\section{Sonuç}

Nadir görülen, Kutanöz Lenfadenom histomorfolojik olarak bazal hücreli karsinoma ile karıştııılabilir. Benign bir deri eki tümörü olup güvenli cerrahi sınırla çıkarılması tedavi için yeterlidir. Yetersiz cerrahi çıkarımdan sonra lokal rekürrens izlenebilir. Baş boyun bölgesine ait nodüler deri lezyonlarında histolojik olarak ayırıcı tanıda akılda tutulmalıdır.

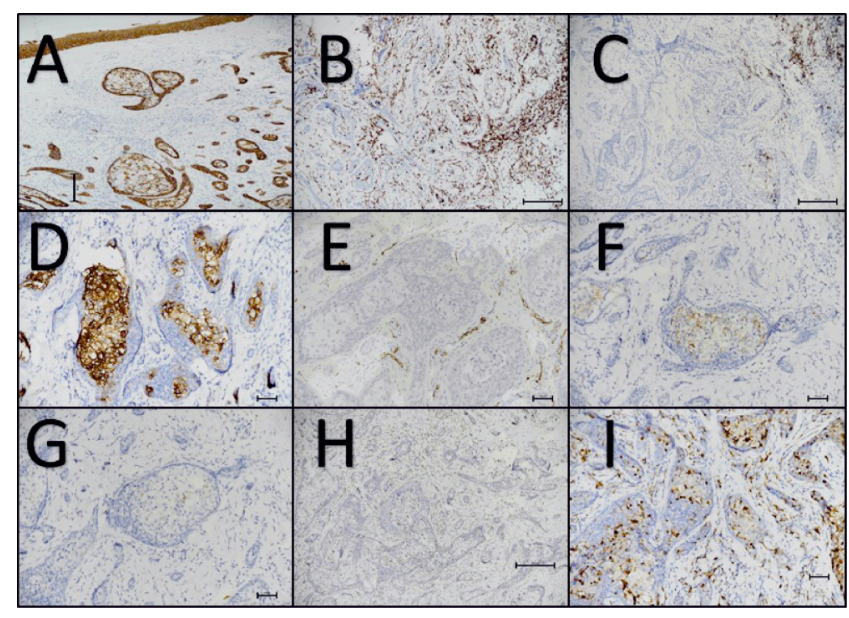

Şekil 2: Tümörün İmmünohisto kimyasal Bulguları.

A: PANCK; bazoloid hücreler ve büyük hücrelerde pozitif (10X)

B: CD3; lobül içi lenfositler ve stromal T lenfositler pozitif (10X)

C: CD20; tümör çevresi B lenfositler pozitif (10X)

D: EMA; lobül içi büyük hücreler pozitif (20X)

E: CD34; stromal damar yapıları pozitif (20X)

F: CD30; lobül içi büyük hücreler pozitif (20X)

G: CD15; lobül içi büyük hücreler az sayıda soluk pozitif (20X)

$\mathrm{H}$ : Bcl-2; tümör içi ve stromal lenfositler pozitif (10X)

I: S100; lobül içi dendritik hücreler pozitif (20X) 
Yazarlık katkısı: Fikir/Hipotez: HHKŞ, YB, BY. Tasarım: YB. Veri toplama/Veri işleme: HHKŞ, YB, BY. Veri analizi: YB. Makalenin hazırlanması: HHKŞ, YB, BY. Makalenin kontrolü: YB.

Etik Kurul Onayı: Gerekli değildir.

Hasta Onayı: Olgu sunumu için hastadan izin alınmıştır.

Hakem Değerlendirmesi: illgili alan editörü tarafından atanan iki farklı kurumda çalışan bağımsız hakemler tarafından değerlendirilmiştir.

\section{References}

1. Santa Cruz DJ, Barr RJ, Headington JT. Cutaneous Lymphadenoma. The American Journal of Surgical Pathology 1991;15: 101-110.

2. Alsadhan A, Taher M, Shokravi M. Cutaneous lymphadenoma. J Am Acad Dermatol 2003; 49:1115-6.

3. Filosa G, Bugatti L, Ciattaglia G. Epitheliolympho-histiocytic tumor: a controversial entity. Eur J Dermatol 1994;4:376-8.

4. Civatte J, Moulonguet-Michau I, Marinho E, Cavelier-Balloy B, Verola O. Epithelio-lymphohistiocytic tumor. Apropos of 3 cases. Ann Dermatol Venereol. 1990;117:441-444.

5. Murphy M, Brierley T, Pennoyer J et al. Lymphotropic adamantinoid trichoblastoma. Pediatr Dermatol. 2007;24:157-61.

6. Botella R, Mackie RM. Cutaneous lymphadenoma: a case report and review of the literature. Br J Dermatol 1993;128:339-41.
Çıkar Çatışması: Yazarlar tarafından çıkar çatışması bildirilmemiştir.

Finansal Destek: Yazarlar tarafından finansal destek almadıkları bildirilmiştir.

7. Tsang WY, Chan JK. So-called cutaneous lymphadenoma: a lymphotropic solid syringoma? Histopathology 1991;19:382-5.

8. Le Boit PE, Burg G, Weedon D, Sarasin A. World Health Organization Classification of Tumours. Pathology and Genetics of Skin Tumours. 3rd Edition. Lyon: 2006 IARC 2006:152-159.

9. Fujimura T, Itoigawa A, Haga T, Aiba S. Cutaneous lymphadenoma: a case report and immunohistochemical study. Case Rep Dermatol 2012;4:50-55.

10. Yu R, Salama S, Alowami S. Cutaneous lymphadenoma:A Rare Case and Brief Review of a Diagnostic Pitfall. Rare Tumors 2014; 6:53-54.

11. Isık A, Fırat D, Peker K, İnal A, Yılmaz I, Celebi, F. Breast Skin Necrosis After Methylene Blue Dye İnjection: Breast İmage. Sakarya Med J 2018; 8:153-156. 